\title{
Changes in Gene Expression within the Extended Amygdala following Binge-Like Alcohol Drinking by Adolescent Alcohol- Preferring (P) Rats
}

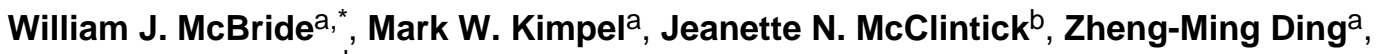 \\ Howard J. Edenberg ${ }^{b}$, Tiebing Liang ${ }^{c}$, Zachary A. Rodd ${ }^{a}$, and Richard L. Bell ${ }^{a}$ \\ anstitute of Psychiatric Research, Department of Psychiatry, Indiana University School of \\ Medicine, Indiana University-Purdue University at Indianapolis, Indianapolis, IN 46202 \\ ${ }^{b}$ Department of Biochemistry \& Molecular Biology, Center for Medical Genomics, Indiana \\ University School of Medicine, Indiana University-Purdue University at Indianapolis, Indianapolis, \\ IN 46202 \\ 'Department of Medicine, Indiana University School of Medicine, Indiana University-Purdue \\ University at Indianapolis, Indianapolis, IN 46202
}

\begin{abstract}
The objective of this study was to determine changes in gene expression within the extended amygdala following binge-like alcohol drinking by male adolescent alcohol-preferring $(\mathrm{P})$ rats. Starting at 28 days of age, $\mathrm{P}$ rats were given concurrent access to 15 and $30 \%$ ethanol for 3 one-h sessions/day for 5 consecutive days/week for 3 weeks. Rats were killed by decapitation $3 \mathrm{~h}$ after the first ethanol access session on the $15^{\text {th }}$ day of drinking. RNA was prepared from micropunch samples of the nucleus accumbens shell (Acb-sh) and central nucleus of the amygdala (CeA). Ethanol intakes were $2.5-3.0 \mathrm{~g} / \mathrm{kg} / \mathrm{session}$. There were 154 and 182 unique named genes that significantly differed (FDR $=0.2$ ) between the water and ethanol group in the Acb-sh and CeA, respectively. Gene Ontology (GO) analyses indicated that adolescent binge drinking produced changes in biological processes involved with cell proliferation and regulation of cellular structure in the Acb-sh, and in neuron projection and positive regulation of cellular organization in the CeA. Ingenuity Pathway Analysis indicated that, in the Acb-sh, there were several major intracellular signaling pathways (e.g., cAMP-mediated and protein kinase A signaling pathways) altered by adolescent drinking, with 3-fold more genes up-regulated than down-regulated in the alcohol group. The cAMP-mediated signaling system was also up-regulated in the $\mathrm{CeA}$ of the alcohol group. Weighted gene co-expression network analysis indicated significant G-protein coupled receptor signaling and transmembrane receptor protein kinase signaling categories in the Acb-sh and $\mathrm{CeA}$, respectively. Overall, the results of this study indicated that binge-like alcohol drinking by adolescent $\mathrm{P}$ rats is differentially altering the expression of genes in the Acb-sh and CeA, some of which are involved in intracellular signaling pathways and may produce changes in neuronal function.
\end{abstract}

\footnotetext{
(C) 2013 Elsevier Inc. All rights reserved.

*Corresponding author, Dr. W. J. McBride, Indiana University School of Medicine, Institute of Psychiatric Research, 791 Union Dr. Indianapolis, IN 46202-4887, Phone: +1-317-274-3820; Fax: +1-317-274-1365; wmcbride@iupui.edu.

Publisher's Disclaimer: This is a PDF file of an unedited manuscript that has been accepted for publication. As a service to our customers we are providing this early version of the manuscript. The manuscript will undergo copyediting, typesetting, and review of the resulting proof before it is published in its final citable form. Please note that during the production process errors may be discovered which could affect the content, and all legal disclaimers that apply to the journal pertain.
} 


\section{Keywords}

alcohol-preferring rat; adolescent binge drinking; nucleus accumbens-shell; central nucleus of the amygdala; gene expression

\section{Introduction}

Alcohol use often begins in the second decade of life, with the first use of alcohol typically occurring in early adolescence (13-14 years of age; Faden 2006). Results from the National Longitudinal Alcohol Epidemiological Survey indicated that individuals initiating alcohol use before 14 years old had a 4-fold higher rate of lifetime alcohol dependence than individuals that initiated use after the age of 20 (Grant and Dawson 1997). Moreover, over half the adolescents interviewed in other studies reported binge drinking episodes (Andersson et al., 2007; Mohshouwer et al., 2008). Twin data suggest a linear relationship between age of first use and rate of alcohol dependence, and suggest common genetic influences on age of initiation of alcohol use and alcohol dependence (Sartor et al, 2009).

Studies carried out with the alcohol-preferring $(\mathrm{P})$ rat indicated that alcohol drinking during adolescence resulted, when tested during adulthood, in a quicker acquisition of operant selfadministration of ethanol, greater resistance to extinction, and greater relapse drinking (Rodd-Henricks et al., 2002), suggesting a higher probability of developing alcohol addiction. These results also suggest that persisting neuronal adaptations occurred following adolescent alcohol drinking.

Examining changes in gene expression resulting from chronic ethanol drinking could provide clues toward identifying genes and gene networks involved in maintaining high alcohol drinking behavior. There have been several studies that applied genomics analyses to examining the effects of ethanol in rodent models (Bell et al., 2009; Kerns et al., 2005; McBride et al., 2010; Mulligan et al., 2006, 2011; Rodd et al., 2008; Saito et al., 2002, 2004; Tabakoff et al., 2009; Treadwell and Singh, 2004). The results of these studies indicated that differences in gene expression between alcohol-drinking rodents and water controls could be detected in several brain regions, and these differences could alter neuronal function.

Animal models have been used to study the influence of genetic factors on the effects of alcohol and on alcohol drinking behavior (reviewed in Bell et al., 2005; McBride and Li, 1998; Murphy et al., 2002). Studies on rats and mice have the advantages of allowing control of ethanol exposure and access to fresh tissues at any time. Kerns et al. (2005) reported that acute i.p. ethanol injections altered expression of genes involved in glucocorticoid signaling, neurogenesis, myelination, neuropeptide signaling, and retinoic acid signaling in three brain regions of C57BL/6J and DBA/2J mice. Rodd et al. (2008) reported that operant ethanol self-administration altered gene expression in the Acb and amygdala of inbred P rats. Another study (Bell et al., 2009) reported gene expression changes in the Acb of $\mathrm{P}$ rats following chronic 24-h free-choice ethanol drinking; significant differences in expression of genes involved in intracellular signaling pathways and transcription factors were found between the alcohol and water groups.

Evidence supports the involvement of the Acb in mediating ethanol drinking (reviewed in Koob et al., 1998; McBride and Li, 1998). In particular, the shell portion of the Acb is involved in supporting reinforcement (Ikemoto et al., 1997) and reinforcing effects of drugs of abuse (reviewed in Kalivas et al., 1993). The central nucleus of the amygdala (CeA) has also been implicated in mediating the effects of ethanol (Koob and Le Moal, 2008; McBride, 2002) and dependence-induced alcohol drinking (Roberts et al., 1996). Few studies on 
changes in gene expression within discrete regions of the extended amygdala following alcohol drinking have been undertaken. McBride et al. (2010) reported the effects of bingelike alcohol drinking by adult male $\mathrm{P}$ rats on changes in gene expression within two regions of the extended amygdala, i.e., the Acb-shell (sh) and central nucleus of the amygdala (CeA). Overall, the results of this study indicated that binge-like alcohol drinking produced region-selective changes in expression of genes that could alter transcription, synaptic function and neuronal plasticity.

There have been few studies examining the effects of adolescent binge drinking on changes in gene expression within the CNS. This is mainly due to the amount of time involved in training most rodents to consume pharmacologically relevant amounts of ethanol. Since the adolescent window is approximately 10-14 days, it is difficult to establish stable ethanol intakes that produce relevant blood levels of ethanol. One study, examining the effects of i.g. administration of ethanol on changes in gene expression (Coleman et al., 2011), reported reduced levels of adult neurotransmitter gene expression, particularly of cholinergic genes.

Because of the involvement of the extended amygdala in regulating alcohol drinking, it would be important to determine the effects of adolescent alcohol drinking on gene expression changes within this system. A peri-adolescent binge-like alcohol drinking procedure has been developed, using $P$ rats, that produces blood ethanol levels of approximately $100 \mathrm{mg} \%$ after $60 \mathrm{~min}$ (Bell et al., 2011). Therefore, the present study was undertaken to determine the effects of binge-like alcohol drinking by $\mathrm{P}$ rats during adolescence on changes in gene expression in the Acb-shell and CeA. The hypothesis to be tested is adolescent alcohol binge drinking will produce changes in the expression of genes associated with neuronal function and synaptic plasticity.

\section{Method}

\subsection{Animals}

Subjects were peri-adolescent (28 days old at the start of the experiment) male selectivelybred $\mathrm{P}$ rats from the $69^{\text {th }}$ generation $(\mathrm{n}=20$ rats). The rats were single-housed on a reverse $12 \mathrm{~h} / 12 \mathrm{~h}$ dark-light cycle (light off at $0900 \mathrm{hr}$ ). Animals had ad libitum access to food and water. The animals used in these experiments were maintained in facilities fully accredited by the Association for the Assessment and Accreditation of Laboratory Animal Care (AAALAC). All research protocols were approved by the institutional animal care and use committee and are in accordance with the guidelines of the Institutional Care and Use Committee of the National Institute on Drug Abuse, National Institutes of Health, and the Guide for the Care and Use of Laboratory Animals (Institute of Laboratory Animal Resources, Commission on Life Sciences, National Research Council 1996).

\subsection{Binge-like drinking procedure}

Starting at 28 days of age (PND 28) P rats $(\mathrm{n}=10)$ were given concurrent access to 15 and $30 \%$ ethanol for three 1-h sessions each day during the night cycle, as previously described (Bell et al., 2011). Sessions were conducted 5 days each week (no ethanol on weekends). Water and food were always available. Rats were killed by decapitation $3 \mathrm{~h}$ after the $1^{\text {st }}$ ethanol access session on the $15^{\text {th }}$ day of drinking (when rats were 49 days old). This 3 -h time-point was selected in an attempt to maximize the response to alcohol on the expression of genes in tissue from rats that have a history of repeated adolescent binge drinking. A water control group $(n=10)$ was killed by decapitation at the same time. Brains were quickly removed and frozen in isopentane in dry ice. Brains were stored at $-80^{\circ} \mathrm{C}$ until they were prepared for sectioning and micro-punching. 


\subsection{Sample collection and microarray procedure}

On the day of preparation of micro-punch samples, brains ( $\mathrm{n}=10$ per group) were transferred to a cryostat set at -6 to $-10^{\circ} \mathrm{C}$ at least $2 \mathrm{~h}$ prior to sectioning. Sections (300 $\mu \mathrm{m})$ were obtained and transferred to glass slides that had been pre-cooled in the cryostat. Micro-punch sampling was done on a frozen stage $\left(-25\right.$ to $\left.-35^{\circ} \mathrm{C}\right)$ with an anatomic microscope equipped with a cool microscope lamp. The stereotaxic atlas of Paxinos and Watson (1998) was used to identify the Acb-sh and CeA. Micro-dissection needles (Fisher Scientific) with an inner diameter of $0.77 \mathrm{~mm}$ were used to obtain both regions. This inner diameter fits within the entire region and minimizes contamination from adjacent tissue. Punches are taken bi-laterally from 2-3 sections. A different fresh sterile micro-punch needle was used for each animal. After withdrawing the micro-punch sample, a distinct demarcated hole remained; this hole was used to validate the micro-dissection method. All equipment used to obtain tissue was treated with RNAse Zap (Ambion, Inc. Austin, TX) to prevent RNA degradation. A second trained individual independently verified the quality of the micro-punch dissections.

The micro-punched samples were immediately homogenized in Trizol reagent (Invitrogen, Carlsbad, CA) and processed according to the manufacturer's protocol, but with twice the suggested ratio of Trizol to tissue (Edenberg et al., 2005). Ethanol precipitated RNA was further purified through RNeasy ${ }^{\circledR}$ columns (Qiagen, Valencia, CA) according to the manufacturer's protocol. The yield, concentration and purity of the RNA were determined by running a spectrum from 210 to $350 \mathrm{~nm}$, and analyzing the ratio of large and small ribosomal RNA bands using an Agilent Bioanalyzer. Yields, purity and quality of the RNA were excellent; RNA integrity numbers (RIN) averaged 8.5 for the samples, showing little or no degradation.

Separate preparations of total RNA were made for the Acb-sh and CeA from each animal. Samples were not pooled. Standard Affymetrix protocols (GeneChip ${ }^{\circledR}$ 3'IVT Express Kit starting with 50 ng of total RNA) were used to synthesize biotinylated cRNA, using the Affymetrix kits for cDNA synthesis, in vitro transcription and sample cleanup. The fragmented, biotinylated cRNA from each independent sample was mixed into $300 \mu \mathrm{l}$ of hybridization cocktail, of which $200 \mu \mathrm{l}$ were used for each sample. Hybridization was carried out for $17 \mathrm{~h}$ at $42^{\circ} \mathrm{C}$. Samples were hybridized to the Affymetrix Rat Genome 230 2.0 GeneChips. Washing and scanning of the GeneChips were carried out according to standard protocols, as previously described (Edenberg et al., 2005; McClintick et al., 2003).

To minimize potential systematic errors, all stages of the experiment were balanced across experimental groups. That is, equal numbers of animals in each group were sacrificed within the same 2-h time frame each day, and equal numbers of RNA preparations from the 2 groups were processed through the labeling, hybridization, washing and scanning protocols on a given day, in a counterbalanced order, using premixes of reagents.

\subsection{Statistical and bioinformatics analysis of microarray data}

Each GeneChip ${ }^{\circledR}$ was scanned using an Affymetrix Model 3000 scanner and underwent image analysis using Affymetrix GCOS software. Microarray data are available from the National Center for Biotechnology Information's Gene Expression Omnibus under accession GSE49042.

Raw Cel files were imported into the statistical programming environment R (R: A language and environment for statistical computing Ver 2.2.0; R Foundation for Statistical Computing, 2005) for further analysis with tools available from the Bioconductor Project (Gentleman et al., 2004). Expression data for the 20 arrays from each of the two regions 
were normalized and converted to $\log (2)$ using the Robust Multichip Average (RMA) method (Irizarry et al., 2003) implemented in the Bioconductor package RMA. As a standardization step to facilitate later comparisons with other experiments, expression levels were scaled such that the mean expression of all arrays was $\log _{2}(1000)$. As we were primarily concerned with identifying genes that could be subjected to further bioinformatic analysis, all probe sets currently annotated by Affymetrix as "expressed sequence tags" or whose gene names contain the words "riken", "predicted", or "similar to" were filtered out. We next filtered out probe sets that were not detectable above background in our samples; this has been shown to reduce noise in microarray experiments (McClintick and Edenberg, 2006). Probe sets that did not have at least $25 \%$ of samples with normalized scaled expression greater than 64 were not analyzed. Linear modeling to calculate gene-wise pvalues for the contrasts of the ethanol group versus water group was performed using the package Limma (Smyth, 2004). Probe sets were considered to be statistically significant at FDR $=0.2$ (calculated according to Storey et al., 2004).

Testing for over-representation of Gene Ontology (GO) biological processes (Harris et al., 2004; Ashburner et al., 2000) and Kyoto Encyclopedia of Genes and Genomes (KEGG) categories was performed using the Bioconductor package GOstats (Gentleman, 2004). Briefly, for each gene set tested, a list of unique Entrez-Gene identifiers was constructed. This list was then compared to the list of all known Entrez-Gene identifiers that are represented on the Affymetrix chipset Rat Genome 230 2.0. Identification of overrepresented GO categories was then accomplished within GOstats using the hypergeometric distribution. GO and KEGG categories were called significant at $\mathrm{p}<0.05$.

Genes differentially expressed at FDR $=0.2$ were uploaded into Ingenuity Pathway Analysis (Ingenuity Systems, www.ingenuity.com). Genes were identified by their Affymetrix probe set id and then mapped to their corresponding objects in the Ingenuity ${ }^{\circledR}$ Knowledge Base. These molecules, called Network Eligible molecules, were overlaid onto a global molecular network developed from information contained in the Ingenuity Knowledge Base. Networks of Network Eligible Molecules were then algorithmically generated based on their connectivity.

To provide a more global network analysis, a weighted gene co-expression network analysis (WGCNA) was also conducted (Zhang and Horvath, 2005), using the Bioconductor (Gentleman et al., 2004) package WGCNA (Langfelder and Horvath, 2008, 2012) within R (R: A language and environment for statistical computing Ver 2.15.0; R Foundation for Statistical Computing, 2013). Briefly, gene expression data of named genes were rankordered according to their ascending $\mathrm{p}$-values obtained from traditional t-testing of the two experimental groups. For WGCNA, default values, including the use of the power function with power $\beta$, were used for all functions with the exception that signed correlation coefficients were used. A cutoff of $p \leq 0.10$ was used to select genes for enrichment in networks that met the criteria of legitimacy for scale free topology (Zhang and Horvath, 2005). Resultant modules were tested for enrichment of various categories of genes using Fisher's Exact Test ( $\mathrm{p} \leq 0.05)$ plus enrichment by cell type (Cahoy et al., 2008). Modules that satisfied these two enrichment criteria were tested for significant ( $\mathrm{p} \leq 0.01)$ GO biologic process categories (Harris et al., 2004; Ashburner et al., 2000). Only significant GO categories with 40 or more genes are presented.

\section{Results}

\subsection{Ethanol intakes}

Scheduled access to ethanol was initiated on PND 28 and was conducted over a 3 week period. Ethanol intakes averaged approximately $2.5-3 \mathrm{~g} / \mathrm{kg}$ for each of the 3 daily sessions 
over the 15-day drinking period (Fig. 1). The highest ethanol intakes were observed during the $1^{\text {st }}$ week; daily ethanol intakes were approximately $8 \mathrm{~g} / \mathrm{kg} /$ day during the $2^{\text {nd }}$ and $3^{\text {rd }}$ week of drinking (Fig. 1).

\subsection{Changes in gene expression in the Acb-sh and CeA}

In the Acb-sh, there were a total of 9,059 named genes and, in the CeA, there were a total of 9,322 named genes. In the Acb-sh, there were 306 probe sets that significantly differed between the ethanol and water groups, 163 of which were named genes, representing 154 unique genes (Table 1). For the $\mathrm{CeA}$, there were 335 probe sets that significantly differed between the ethanol and water groups, 190 of which were named genes, representing 182 unique gens (Table 1).

In the Acb-sh, there were 154 unique named genes that were differentially altered by adolescent alcohol drinking (Supplemental Table A). Approximately $65 \%$ of these genes had a fold-change of 1.15 or higher, and 80 genes (52\%) were down-regulated. In the CeA, there were 182 unique named genes that were differentially altered by adolescent alcohol drinking (Supplemental Table B). Approximately $70 \%$ of these genes had a fold-change of 1.15 or higher, and 84 genes (46\%) were down-regulated. There were 26 genes in common between the 2 regions that were significantly altered by adolescent alcohol drinking (Table 2). All 26 genes had the same directional change in both regions, with nearly identical magnitudes of change.

\subsection{Bioinformatics analyses of changes in gene expression}

GO analysis indicated there were 7 and 6 significant biological processes categories with 10 or more genes that differed between the water and ethanol groups in the Acb-sh and CeA, respectively (Table 3). Several of the categories in the Acb-sh involved developmental processes and cell proliferation, but none of these appeared to be directly related to neuronal development. One category (regulation of anatomical structure morphogenesis) may relate to neuronal morphological alterations. On the other hand, in the $\mathrm{CeA}$, there were several categories that could be related to neuronal function, i.e., cell morphogenesis involved in neuron differentiation, neuron projection morphogenesis, positive regulation of cellular component organization, and signal release.

KEGG analysis indicated 5 significant categories in the Acb-sh, containing 5 or more genes; in the $\mathrm{CeA}$, there was only 1 category that had this number of genes (Table 3 ). The one category in the CeA (Neuroactive ligand-receptor interaction) was also found in the Acb-sh.

Ingenuity ${ }^{\circledR}$ pathways analysis indicated 22 significant pathways with 5 or more genes that were altered in the Acb-sh by ethanol drinking, whereas only 4 canonical pathways were observed in the CeA (Table 4). In the Acb-sh, several major intracellular signaling pathways (i.e., cAMP-mediated, glucocorticoid receptor, G-protein coupled receptor and protein kinase A signaling pathways) were altered by adolescent alcohol drinking. Although cAMPmediated signaling was observed for both regions, there was only one gene in common within this pathway, i.e., Duspl. In all 4 signaling pathways in the Acb-sh, there were approximately 3-fold more genes with higher expression in the ethanol group compared to control values. In the cAMP-mediated signaling pathway in the CeA, 5 of the 6 genes were up-regulated in the alcohol group.

For the WGCNA, only by using a very liberal p-value of 0.10 as the cutoff for gene inclusion (2193 genes in the Acb-shell; 2395 genes in the CeA) did the resultant networks meet the criteria for scale free topology (Zhang \& Horvarth, 2005). Modular colors indicate clusters of highly interconnected genes and are randomly assigned by the program. In the 
Acb-sh, the Blue module (neuronal enrichment) contained 21 significant GO categories with 40 or more genes; in the $\mathrm{CeA}$, the Yellow module contained one category and the Turquoise module (astrocytes and oligodendrocytes enrichment) contained 19 GO categories with 40 or more genes (Table 5). There were no categories that were similar between the Acb-sh and $\mathrm{CeA}$. However, there were two signaling pathways that could alter neuronal function in each region, the G-protein coupled receptor signaling pathway in the Acb-sh and the transmembrane receptor protein tyrosine kinase signal pathway in the CeA.

\subsection{Validation of key genes}

Sufficient RNA was available in the Acb-sh samples to validate a few key genes using qRTPCR. Five genes were selected (Table 6); these genes were significantly different in both the Acb-sh and CeA between the alcohol drinking and water control groups and had a foldchange of approximately 1.4 or higher in the Acb-sh. There was excellent agreement between the qRT-PCR values and the values obtained with the microarray procedure (Table $6)$.

\section{Discussion}

The major findings of this study are that(a) adolescent male P rats will consume $8-10 \mathrm{~g}$ ethanol/kg body wt/day with 3 daily binge-like drinking episodes; (b) significant changes in gene expression were found in both the CeA and Acb-sh, with 26 genes in common between the two regions; (c) there was little overlap between the 2 regions in the GO and KEGG pathways altered by adolescent binge-like drinking; and (d) adolescent alcohol drinking produced changes in several intracellular signaling pathways in both regions.

The average ethanol intakes in the present study (approximately $8 \mathrm{~g} / \mathrm{kg} / \mathrm{day}$ ) were comparable to the daily intakes previous reported for adolescent $\mathrm{P}$ rats using the same bingelike drinking protocols (Bell et al., 2011). Blood ethanol levels (BELs) reported in this study (Bell et al., 2011) exceeded $80 \mathrm{mg} \%$ and approached $100 \mathrm{mg} \%$ on a daily basis, indicating that the adolescent $\mathrm{P}$ rats were attaining intoxicating blood ethanol levels on a daily basis.

Adolescent binge-like drinking altered the expression of 154 and 182 unique named genes in the Acb-sh and CeA, respectively (Supplemental Tables A \& B), with 26 genes in common (Table 2). Although the Acb-sh and $\mathrm{CeA}$ are both involved in regulating alcohol drinking (reviewed in Koob et al., 1998; McBride and Li, 1998; McBride 2002), these 2 regions have different inputs and intrinsic neuronal circuits from each other (Cassell et al., 1999; Meredith 1999). However, there are some similarities, e.g., both receive DA inputs from the VTA and the principal type of neuron in both regions is the medium-sized GABAergic spiny neuron (Cassell et al., 1999; Meredith 1999). The common genes altered in both regions could be the result of the actions of ethanol on the same types of neurons and/or glia, whereas the unique effects of ethanol on gene expression within each region may be a result of ethanol acting on the different inputs to each region and the unique neuronal circuitries found within each region.

The bioinformatics analyses (Tables 3-5) suggested that different biological systems were being altered by adolescent binge-like drinking within each region. GO analyses (Table 3) indicated that expression of genes involved in neuron projection morphogenesis and positive regulation of cellular component organization was significantly altered by ethanol drinking in the CeA, suggesting that adolescent binge drinking may be altering neuronal function within this region. KEGG analyses (Table 3 ) indicated that adolescent drinking produced changes in expression of genes involved in neuroactive ligand-receptor interaction, suggesting that ethanol may be altering synaptic transmission within both regions. In addition, KEGG analyses indicated significant changes in expression of genes involved in 
ErbB and Wnt signaling pathways (Table 3). Wnt pathways are involved in multiple intracellular signaling cascades that promote neuronal survival (Kikuchi et al., 2011; Scott \& Brann 2013). The ErbBs are a family of receptor tyrosine kinases that allow cells to interact with the extracellular environment and transducer signals to the nucleus for proper cellular morphogenesis and function (Wadugu and Kuhn 2012; Sanchez-Soria and Camenisch 2010). These results suggest that adolescent binge-like drinking by $P$ rats is significantly altering intracellular signaling pathways that could alter transcription in the Acb-sh. WGCNA supported the findings of the GO and KEGG analysis and indicated alterations in intracellular signaling pathways and synaptic transmission between the ethanol and water groups (Table 5).

Ingenuity Pathway analysis revealed that many more categories were significantly altered by adolescent drinking in the Acb-sh than in the CeA (Table 4). The cAMP signaling pathways in both regions had a significant number of genes altered by adolescent drinking. In both regions, there were more genes up-regulated than down-regulated in the cAMP signaling pathways (7:2 ratio and 5:1 ratio in Acb-sh and CeA, respectively), suggesting ethanol exposure enhanced the activity of this pathway. However, there was only one gene (Dusp 1) in common in the cAMP signaling pathway between the 2 regions, suggesting that the cellular mechanisms underlying the effects of ethanol are likely different in each region. It is noteworthy that Duspl also responds to glucocorticoids and is located in ethanol preference rat QTL $\underline{\text { Alc5}}$. Paralleling the present results, another study from our laboratory revealed chronic ethanol drinking by adult $P$ rats resulted in increased Duspl gene expression in the Acb-sh (McBride et al., 2010) but reduced gene expression in the ventral tegmental area (McBride et al., 2013).

Expression of genes involved in HMGB1 (high-mobility group box 1) signaling was also altered in both regions (Table 4). HMGB1 is a PKR-dependent, DNA-binding protein and cytokine that binds to toll-like receptors (TLRs) having pro-inflammatory properties (Kang and Tang, 2012; Yang et al., 2010). Increased activity in this signaling pathway (i.e., PKRHMGB1-TLR) may be a response to chronic high brain levels of ethanol produced by adolescent binge-like drinking with an expected influence on neuronal function, as similarly reported by Vetreno and Crews (2012; also see Crews et al., 2013).

In the Acb-sh, several signaling pathways appear to be activated by chronic adolescent binge-drinking of $\mathrm{P}$ rats, as indicated by the number of genes up-regulated compared to the number down-regulated in the cAMP-mediated signaling (7:2 ratio), glucocorticoid receptor signaling (7:2 ratio), RAR activation (5:1 ratio), G-protein coupled receptor signaling (8:3 ratio), and protein kinase A signaling (7:2 ratio) pathways (Table 4). The more global WGCNA was consistent with the IPA and provided support for the observed increase in Gprotein coupled receptor signaling and alterations in synaptic transmission. Although the WGCNA indicated many different biological categories were altered by adolescent alcohol drinking in the $\mathrm{CeA}$, there was only one signaling pathway listed, i.e., transmembrane receptor protein tyrosine kinase (Table 5). Overall, these results suggest that in the Acb-sh, and to a lesser extent in the $\mathrm{CeA}$, adolescent alcohol drinking by $\mathrm{P}$ rats is producing significant developmental alterations in intracellular signaling pathways.

Among the 26 genes in common between the Acb-sh and CeA (Table 2), 14 were upregulated and 12 were down-regulated in the alcohol drinking group compared to the water control group. In general, several of the genes that had higher expression levels could result in enhanced neuronal function, involving intracellular transport (Kif15; Hirokawa et al., 2009) and cytoskeletal organization (Klhl23; Wu and Gong 2004), increased Kainate (Neto2; Copits and Swanson 2012) and NPY (Npy5r) receptor function, vesicle docking (Nsf; Ramakrishman et al., 2012), and mitochondrial function (Chchd5, Phb2, Slc25; Banci 
et al., 2009; Artal-Sanz and Tavernarakis 2009; Fiermonte et al., 2009). Kif15 is synonymous with kinesin-12 a cytoskeletal motor protein, which also affects axonal growth, navigation and branching (Liu et al., 2010). Nsf has been reported to be up-regulated in the $\mathrm{CeA}$ with chronic ethanol-drinking by adult $\mathrm{P}$ rats (McBride et al., 2010). In this previous study, $N s f$ was identified in an Ingenuity ${ }^{\circledR}$ pathway that included multiple glutamatergic and GABAergic receptor-associated genes (McBride et al., 2010). On the other hand, the higher expression of 2 genes (Cyr61 and Tnfrsf1 1b; Chen and Lau 2009; Hope et al., 2010) indicate that the level of alcohol drinking may be producing neuro-inflammation. Cyr61 is synonymous with CCN1 an extracellular matrix protein involved in Fas-mediated apoptosis (Juric et al., 2009). In addition, the $N p y 5 r$ gene has been reported to be associated with both alcohol and cocaine dependence in human studies (Wetherill et al., 2008).

Many of the genes that had lower expression levels in the alcohol than water group could result in altered transcription (Chd7, Klf3, Mga, Mtfl, Spl; Kim and Layman 2011; Moore et al., 2011; Hurlin et al., 1999; Giedroc et al., 2001; Lomberk and Urrutia 2005), and reduced response to oxidative (Angptl4; Zhu et al., 2012) or other cellular (Cls, Cdknla, Limdl; Schumaker et al., 1986; Mergenthaler et al., 2013; Foxler et al., 2012) stresses. These results suggest that adolescent binge-like alcohol drinking may have reduced the capabilities of many of the neurons and glia in the Acb-sh and CeA to adequately regulate the levels of reactive oxygen species. Interestingly, Limdl was identified as a high alcohol consumption candidate gene in a meta-analysis study with mice (Mulligan et al., 2006).

Adolescent binge-like exposure reduced basal a-MSH immuno-reactivity in the CeA (Lerma-Cabrera et al., 2013). Another study indicated that adolescent consumption of a sweetened alcohol solution by female Wistar rats reduced the number of CRF immunoreactive cells in the CeA (Karanikas et al., 2013). A third study (Alaux-Cantin et al., 2013), using binge-like ethanol administration, reported lower c-fos immunoreactivity in the Acb and enduring alterations in the expression of Penk and Slc6a4. These results are consistent with the results of the present study indicating that the Acb and CeA may be vulnerable to the effects of ethanol during adolescence. In addition, the WGCNA indicated a significant number of GO categories associated with astrocytes and oligodendrocyte functions. Alterations in glial function have been produced by alcohol exposure and may contribute to alcohol drinking behavior (Lee et al., 2013; Nam et al., 2012; Paul \& Medina 2012).

A previous study (McBride et al., 2010) examined the effects of adult binge-like drinking on gene expression in the Acb-sh and CeA of adult P rats. A similar procedure of 3 one-h sessions per day during the dark cycle for 5 consecutive days each week was used in this previous study. The ethanol intakes and BELs for the adolescent and adult $\mathrm{P}$ rats were similar (Bell et al., 2011; McBride et al., 2010). In the Acb-sh, although there were 4 genes (Hhex, Nyw1, Usp18, Zfp36l1) in common between the present study (Supplemental Table A) and the previous adult study (McBride et al., 2010), the direction of change was not similar. In the CeA, there were 8 genes in common between the adult and adolescent findings, with 6 genes (Asrd, Cxcl12, Nsf, Tfrc, Ube2b, Zc3h8) changing in the same direction in both studies and only 2 genes (Ier2, Nfil3) changing in opposite directions. The overall general paucity of common genes between the adult and adolescent findings in the Acb-sh and CeA may illustrate the unique effects that ethanol has during the peri-adolescent period.

Within the Acb-sh, there were several biological systems (using GO, KEGG and IPA analyses) that were significantly changed following both peri-adolescent and adult binge like drinking. These included glucocorticoid receptor (GR) signaling, Wnt signaling, regulation of anatomical structure morphogenesis, and cancer. Changes in GR and Wnt signaling could alter the transcription of multiple genes affecting a variety of cellular functions (Ratman et 
al., 2013; Kikuchi et al., 2011). Even though alcohol drinking by adolescent and adult P rats altered similar biological systems, the mechanisms underlying alcohol's actions appear to be different since there are so few genes in common that were changed in both studies.

In the $\mathrm{CeA}$, there were some common biological systems that overlap between the present study and the adult study (McBride et al., 2010), these included neuroactive ligand-receptor interaction (Table 3), neuron projection morphogenesis (Table 3) and positive regulation of cell component organization (Table 3 ). In the adult, the genes associated with neuron projections and regulation of cell organization were mainly up-regulated suggesting an overall positive effect of binge drinking on these biological systems.

Overall, the effects of binge drinking by $\mathrm{P}$ rats on gene expression appear to be age and region dependent. Although there are some biological systems in common between the effects of adolescent vs. adult ethanol intake, there are few genes in common within these systems, suggesting different mechanisms of action and their associated outcomes at the 2 different ages. Moreover, there was only one biological system in common between the 2 regions, which likely reflects the different inputs to and neuronal circuits within the Acb-sh vs, the CeA.

The effects of repeated i.g. administration of ethanol $(5 \mathrm{~g} / \mathrm{kg}$ once per day for 10 consecutive days) during adolescence (PND 28 - 37) were studied on changes of gene expression in the whole brain of C57BL/6 mice (Coleman et al., 2011). In this study, RT-PCR arrays targeting genes for different peptide, cholinergic, monoamine, GABA and glycine receptors were used. In general, measurements taken on PND 38 indicated reduced expression of genes for these receptors in the ethanol-treated group compared to the controls. These findings are in contrast to the present results where expression of genes for different receptors were increased in the Acb-sh (Adora2b, Adrb2, Npy5r; Supplemental Table A) and CeA (Gabrb3, Grm7, Hrh3, Htrld, Npy5r, Tfrc; Supplemental Table B) of the binge drinking group vs. the water control. In no case was the expression of genes for any receptor significantly decreased by adolescent binge-like drinking in the present study. The contrast in the results between the present study and the findings of Coleman and colleagues (2011) could be due to a combination of factors: (a) i.g. bolus administration of ethanol, which produced BELs of $\sim 280 \mathrm{mg} \%$ vs. binge-like drinking, which produced BELs of $\sim 100 \mathrm{mg} \%$; (b) whole brain vs. discrete regions; and/or (c) inbred mouse vs. selectively bred rat.

In summary, adolescent binge-like alcohol drinking (ethanol intakes of $2.5-3.0 \mathrm{~g} / \mathrm{kg}$ / session) by $\mathrm{P}$ rats produced effects on the expression of genes involved in multiple biological cellular pathways in the Acb-sh and CeA. These pathways included several important intracellular signaling systems, e.g., cAMP-mediated, glucocorticoid receptor signaling, protein kinase A signaling, etc, with more genes up-regulated than downregulated in the alcohol group. Some of the changes in gene expression produced by adolescent binge-like drinking may be unique to the selectively bred $\mathrm{P}$ rat, and/or unique to this stage of development.

\section{Supplementary Material}

Refer to Web version on PubMed Central for supplementary material.

\section{Acknowledgments}

This study was supported by AA07611, and INIA grants AA013522, AA016652, AA016660 and AA020892, and INGEN® (which is partially funded by Lilly Endowment Inc.). None of the authors has a conflict of interest associated with this research. The content of this manuscript is solely the responsibility of the authors and does not necessarily represent the official views of the NIAAA or NIH. 


\section{References}

Alaux-Cantin S, Warnault V, Legastelois R, Botia B, Pierrefiche O, Vilpoux C, Naassila M. Alcohol intoxications during adolescence increase motivation for alcohol in adult rats and induce neuroadaptations in the nucleus accumbens. Neuropharmacology. 2013; 67:521-531. [PubMed: 23287538]

Andersson B, Hibell B, Beck F, Choquer M, Kokkevi A, Molinaro S, Nociar A, Sieroslawski J, Trapencieris M. Alcohol and drug use among European 17-18 year old students. Data from the ESPAD project. The Swedish Council for Information on Alcohol and Other Drugs (CAN) and the Pompidou Group at the Council of Europe. Modintrychoffset AB, Stockholm. 2007

Artal-Sanz M, Tavernarakis N. Prohibitin and mitochondrial biology. Trends Endocrinol Metab. 2009; 20:394-401. [PubMed: 19733482]

Ashburner M, Ball CA, Blake JA, Botstein D, Butler H, Cherry JM, Davis AP, Dolinski K, Dwight SS, Eppig JT, Harris MA, Hill DP, Issel-Tarver L, Kasarskis A, Lewis S, Matese JC, Richardson JE, Ringwald M, Rubin GM, Sherlock G. Gene ontology: tool for the unification of biology. The Gene Ontology Consortium. Nat Genet. 2000; 25:25-29. [PubMed: 10802651]

Banci L, Bertini I, Ciofi-Baffoni S, Tokatidis K. The coiled coil-helix-coiled coil-helix proteins may be redox proteins. FEBS Lett. 2009; 583:1699-1702. [PubMed: 19345215]

Bell, RL.; Rodd, ZA.; Murphy, JM.; McBride, WJ. Use of selectively bred alcohol-preferring rats to study alcohol abuse, relapse and craving. In: Preedy, VR.; Watson, RR., editors. Comprehensive handbook of alcohol related pathology. Vol. Vol. 3. New York: Academic Press; 2005. p. 1517-1533.

Bell RL, Kimpel MW, McClintick JN, Strother WN, Carr LG, Liang T, Rodd ZA, Mayfield RD, Edenberg HJ, McBride WJ. Gene expression changes in the nucleus accumbens of alcoholpreferring rats following chronic ethanol consumption. Pharmacol Biochem Behav. 2009; 94:131147. [PubMed: 19666046]

Bell RL, Rodd ZA, Smith RJ, Toalston JE, Franklin KM, McBride WJ. Modeling binge-like ethanol drinking by peri-adolescent and adult P rats. Pharmacol Biochem Behav. 2011; 100:90-97. [PubMed: 21824488]

Cahoy JD, Emery B, Kaushal A, Foo LC, Zamanian JL, Christopherson KS, et al. A transcriptome database for astrocytes, neurons, and oligodendrocytes: a new resource for understanding brain development and function. J Neurosci. 2008; 28:264-278. [PubMed: 18171944]

Cassell MD, Freedman LJ, Shi C. The intrinsic organization of the central extended amygdala. Ann NY Acad Sci. 1999; 877:217-241. [PubMed: 10415652]

Chen CC, Lau LF. Functions and mechanisms of action of CCN matricellular proteins. Int J Biochem Cell Biol. 2009; 41:771-783. [PubMed: 18775791]

Coleman LG Jr, He J, Lee J, Styner M, Crews FT. Adolescent binge drinking alters adult brain neurotransmitter gene expression, behavior, brain regional volumes, and neurochemistry in mice. Alcohol Clin Exp Res. 2011; 35:671-688. [PubMed: 21223304]

Copits BA, Swanson GT. Dancing partners at the synapse: auxiliary subunits that shape kainite receptor function. Nat Rev Neurosci. 2012; 13:675-686. [PubMed: 22948074]

Crews FT, Qin L, Sheedy D, Vetreno RP, Zou J. High mobility group box 1/toll-like receptor danger signaling increases brain neuroimmune activation in alcohol dependence. Biol Psychiatry. 2013; 73:602-612. [PubMed: 23206318]

Edenberg HJ, Strother WN, McClintick JN, Tian H, Stephans M, Jerome RE, Lumeng L, L T-K, McBride WJ. Gene expression in the hippocampus of inbred alcohol-preferring and -nonpreferring rats. Genes Brain Behav. 2005; 4:20-30. [PubMed: 15660665]

Faden VB. Trends in initiation of alcohol use in the United States 1975 to 2003. Alcohol Clin Exp Res. 2006; 30:1011-1022. [PubMed: 16737460]

Fiermonte G, Paradies E, Todisco S, Marobbio CM, Palmieri F. A novel member of solute carrier family 25 (SLC25A42) is a transporter of coenzyme A and adenosine 3', 5'-diphosphate in human mitochondria. J Biol Chem. 2009; 284:18152-18159. [PubMed: 19429682]

Foxler DE, Bridge KS, James V, Webb TM, Mee M, Wong SC, Feng Y, Constantin-Teodosiu D, Petursdottir TE, Bjornsson J, Ingvarsson S, Ratcliffe PJ, Longmore GD, Sharp TV. The LIMD1 
protein bridges an association between the prolyl hydroxylases and VHL to repress HIF-1 activity. Nat Cell Biol. 2012; 14:201-208. [PubMed: 22286099]

Gentleman RC. Using GO for statistical analysis. Proc COMPSTAT. 2004:171-180.

Gentleman RC, Carey VJ, Bates DM, Bolstad B, Dettling M, Dudoit S, Ellis B, Gautier L, Ge Y, Gentry J, Hornik K, Hothorn T, Huber W, Iacus S, Irizarry R, Leisch F, Li C, Maechler M, Rossini AJ, Sawitzki G, Smith C, Smyth G, Tierney L, Yang JY, Zhang J. Bioconductor: open software development for computational biology and bioinformatics. Genome Biol. 2004; 5:R80. [PubMed: 15461798]

Giedroc DP, Chen X, Apuy JL. Metal response element (MRE)-binding transcription factor-1 (MTF-1): structure, function and regulation. Antioxid Redox Signal. 2001; 3:577-596. [PubMed: 11554446]

Grant BF, Dawson DA. Age of onset of alcohol use and its association with DSM-IV alcohol abuse and dependence: results from the National Longitudinal Alcohol Epidemiologic Survey. J Subst Abuse. 1997; 9:103-110. [PubMed: 9494942]

Harris MA, Clark J, Ireland A, Lomax J, Ashburner M, Foulger R, Eilbeck K, Lewis S, Marshall B, Mungall C, Richter J, Rubin GM, Blake JA, Bult C, Dolan M, Drabkin H, Eppig JT, Hill DP, Ni L, Ringwald M, Balakrishnan R, Cherry JM, Christie KR, Costanzo MC, Dwight SS, Engel S, Fisk DG, Hirschman JE, Hong EL, Nash RS, Sethuraman A, Theesfeld CL, Botstein D, Dolinski K, Feierbach B, Berardini T, Mundodi S, Rhee SY, Apweiler R, Barrell D, Camon E, Dimmer E, Lee V, Chisholm R, Gaudet P, Kibbe W, Kishore R, Schwarz EM, Sternberg P, Gwinn M, Hannick L, Wortman J, Berriman M, Wood V, de la Cruz N, Tonellato P, Jaiswal P, Seigfried T, White R. The Gene Ontology (GO) database and informatics resource. Nucleic Acids Res. 2004; 32 Database issue, D258-261.

Hirokawa N, Noda Y, Tanaka Y, Niwa S. Kinesin superfamily motor proteins and intracellular transport. Nat Rev Mol Cell Biol. 2009; 10:682-696. [PubMed: 19773780]

Hope S, Melle I, Aukrust P, Agartz I, Lorentzen S, Steen NE, Diurovic S, Ueland T, Andreassen OA. Osterprotegerin levels in patients with severe mental disorders. J Psychiatry Neurosci. 2010; 35:304-310. [PubMed: 20569643]

Hurlin PJ, Steingrimsson E, Copeland NG, Jenkins NA, Eisenman RN. Mga, a dual-specificity transcription factor that interacts with Max and contains a T-domain DNA-binding motif. EMBO J. 1999; 18:7019-7028. [PubMed: 10601024]

Ikemoto S, Glazier BS, Murphy JM, McBride WJ. Role of D1 and D2 receptors in the nucleus accumbens in mediating reward. J Neurosci. 1997; 17:8580-8587. [PubMed: 9334429]

Irizarry RA, Hobbs B, Collin F, Beazer-Barclay YD, Antonellis KJ, Scherf U, Speed TP. Exploration, normalization, and summaries of high density oligonucleotide array probe level data. Biostatistics. 2003; 4:249-264. [PubMed: 12925520]

Juric V, Chen C-C, Lau LF. Fas-mediated apoptosis is regulated by the extracellular matrix protein CCN1 (CYR61) in vitro and in vivo. Mol Cell Biol. 2009; 29:3266-3279. [PubMed: 19364818]

Kalivas, PW.; Churchill, L.; Klitenick, MA. The circuitry mediating the translation of motivational stimuli into adaptive motor responses. In: Kalivas, PW.; Barnes, CD., editors. Limbic motor circuits and neuropsychiatry. Baco Raton, Fl: CRC Press; 1993. p. 237-288.

Kang R, Tang D. PKR-dependent inflammatory signals. Sci Signal. 2012; 5(247 pe47):1-4. [PubMed: 22234611]

Karanikas CA, Lu Y-L, Richardson HN. Adolescent drinking targets corticotrophin-releasing factor peptide-labeled cells in the central amygdala of male and female rats. Neuroscience. 2013; 249:98-105. [PubMed: 23628776]

Kerns RT, Ravindranathan A, Hassan S, Cage MP, York T, Sikela JM, Williams RW, Miles MF. Ethanol-responsive brain region expression networks: Implications for behavioral responses to acute ethanol in DBA/2J versus C57BL/6J mice. J Neurosci. 2005; 25:2255-2266. [PubMed: 15745951]

Kikuchi A, Yamamoto H, Sato A, Matsumoto S. New insights into the mechanisms of Wnt signaling pathway activation. Int Rev Cell Mol Biol. 2011; 291:21-71. [PubMed: 22017973] 
Kim HG, Layman LC. The role of CHD7 and the newly identified WDR11 gene in patients with idiopathic hypogonadotropic hypogonadism and Kallmann syndrome. Mol Cell Endocrinol. 2011; 346:74-83. [PubMed: 21856375]

Koob GF, Le Moal M. Review. Neurobiological mechanisms for opponent motivational processes in addiction. Philos Trans R Soc Lond B Biol Sci. 2008; 363:3113-3123. [PubMed: 18653439]

Koob GF, Roberts AJ, Schulteis G, Parsons LF, Heyser CL, Hyytia P, et al. Neurocircuitry targets in ethanol reward and dependence. Alcohol Clin Exp Res. 1998; 22:3-9. [PubMed: 9514280]

Langfelder P, Horvath S. WGCNA: an R package for weighted correlation network analysis. BMC Bioinformatics. 2008; 9:559. [PubMed: 19114008]

Langfelder P, Horvath S. Fast R functions for robust correlations and hierarchical clustering. J Statistical Software. 2012:46.

Lee MR, Ruby CL, Hinton DJ, Choi S, Adams CA, Young-Kang N, Choi DS. Striatal adenosine signaling regulates EAAT2 and astrocytic AQP4 expression and alcohol drinking in mice. Neuropsychopharmacology. 2013; 38:437-445. [PubMed: 23032072]

Lerma-Cabrera JM, Carvajal F, Alcaraz-Iborra M, de la Fuente L, Navarro M, Thiele TE, Cubero I. Adolescent binge-like ethanol exposure reduces basal a-MSH expression in the hypothalamus and the amygdala of adult rats. Pharmacol Biochem Behav. 2013; 110:66-74. [PubMed: 23792540]

Liu M, Nadar VC, Kozielski F, Kozlowska M, Yu W, Baas PW. Kinesin-12, a mitotic microtubuleassociated motor protein, impacts axonal growth, navigation and branching. J Neurosci. 2010; 30:14896-14906. [PubMed: 21048148]

Lomberk G, Urrutia R. The family feud: turning off Sp1 by Sp1-like KLF proteins. Biochem J. 2005; 392:1-11. [PubMed: 16266294]

McBride WJ. Central nucleus of the amygdala and the effects of alcohol and alcohol-drinking behavior in rodents. Pharmacol Biochem Behav. 2002; 71:509-515. [PubMed: 11830185]

McBride WJ, Li T-K. Animal models of alcoholism: neurobiology of high alcohol-drinking behavior in rodents. Crit Rev Neurobiol. 1998; 12:339-369. [PubMed: 10348615]

McBride WJ, Kimpel MW, Schultz JA, McClintick JN, Edenberg HJ, Bell RL. Changes in gene expression in regions of the extended amygdala of alcohol-preferring rats after binge-like alcohol drinking. Alcohol. 2010; 44:171-183. [PubMed: 20116196]

McBride WJ, Kimpel MW, McClintick JN, Ding Z-M, Hauser SR, Edenberg HJ, Bell RL, Rodd ZA. Changes in gene expression within the ventral tegmental area following repeated excessive bingelike alcohol drinking by alcohol-preferring (P) rats. Alcohol. 2013; 47:367-380. [PubMed: 23714385]

McClintick JN, Edenberg HJ. Effects of filtering by Present call on analysis of microarray experiments. BMC Bioinformatics. 2006; 7:49. [PubMed: 16448562]

McClintick JN, Jerome RE, Nicholson CR, Crabb DW, Edenberg HJ. Reproducibility of oligonucleotide arrays using small samples. BMC Genomics. 2003; 4:1-15. [PubMed: 12529184]

Meredith GE. The synaptic framework for chemical signaling in nucleus accumbens. Ann NY Acad Sci. 1999; 877:140-156. [PubMed: 10415648]

Mergenthaler P, Muselmann C, Sunwoldt J, Isaev NK, Wielock T, Dimagl U, Meisel A, Ruscher K. A functional role of the cyclin-dependent kinase inhibitor 1 (p21 (WAF1/CIP1)) for neuronal preconditioning. J Cereb Blood Flow Metab. 2013; 33:351-355. [PubMed: 23299246]

Monshouwer K, Verdurmen J, Van Dorsselaer S, Smit E, Gorter A, Vollebergh W. Youth and risk behavior 2007: data from research among pupils and students. Trimbos Institut. 2008 Utrecht.

Moore DL, Apara A, Goldberg JL. Kruppel-like transcription factors in the nervous system: novel players in neurite outgrowth and axon regeneration. Mol Cell Neurosci. 2011; 47:233-243. [PubMed: 21635952]

Mulligan MK, Ponomerav I, Hitzemann RJ, Belknap JK, Tabakoff B, Harris RA, Crabbe JC, Blednov YA, Grahame NJ, Phillips TJ, Finn DA, Hoffman PL, Iyer VR, Koob GJ, Bergeson SE. Toward understanding the genetics of alcohol drinking through transcriptome meta-analysis. Proc Natl Acad Sci USA. 2006; 103:6368-6373. [PubMed: 16618939]

Mulligan MK, Rhodes JS, Crabbe JC, Mayfield RD, Harris RA, Ponomarev I. Molecular profiles of drinking alcohol to intoxication in C57BL/6J mice. Alcohol Clin Exp Res. 2011; 35:659-670. [PubMed: 21223303] 
Murphy JM, Stewart RB, Bell RL, Badia-Elder NE, Carr LG, McBride WJ, et al. Phenotypic and genotypic characterization of the Indiana University rat lines selectively bred for high and low alcohol preference. Behav Genet. 2002; 32:363-388. [PubMed: 12405517]

Nam HW, McIver SR, Hinton DJ, Thakkar MM, Sari Y, Parkinson FE, Haydon PG, Choi DS. Adenosine and glutamate signaling in neuron-glial interactions: implications in alcoholism and sleep disorders. Alcohol Clin Exp Res. 2012; 36:1117-1125. [PubMed: 22309182]

Paul AP, Medina AE. Overexpression of serum response factor in astrocytes improves neuronal plasticity in a model of early alcohol exposure. Neuroscience. 2012; 221:193-202. [PubMed: 22742904]

Paxinos, G.; Watson, C. The Rat Brain in Stereotaxic Coordinates. New York: Academic Press; 1998.

Ramakrishnan NA, Drescher MJ, Drescher DG. The SNARE complex in neuronal and sensory cells. Mol Cell Neurosci. 2012; 50:58-69. [PubMed: 22498053]

Ratman D, Vanden Berghe W, Dejager L, Libert C, Tavernier J, Beck IM, DeBosscher K. How glucocorticoid receptors modulate the activity of other transcription factors: a scope beyond tethering. Mol Cell Endocrinol. 2013; 380:41-54. [PubMed: 23267834]

Roberts AJ, Cole M, Koob GF. Intra-amygdala muscimol decreases operant ethanol selfadministration in dependent rats. Alcohol Clin Exp Res. 1996; 20:1289-1298. [PubMed: 8904984]

Rodd ZA, Kimpel MW, Edenberg HJ, Bell RL, Strother WN, McClintick JN, Carr LG, Liang T, McBride WJ. Differential gene expression in the nucleus accumbens with ethanol selfadministration in inbred alcohol-preferring rats. Pharmacol Biochem Behav. 2008; 89:481-498. [PubMed: 18405950]

Rodd-Henricks ZA, Bell RL, Kuc KA, Murphy JM, McBride WJ, Lumeng L, Li T-K. Effects of ethanol exposure on subsequent acquisition and extinction of ethanol self-administration and expression of alcohol-seeking behavior in adult alcoholpreferring $(\mathrm{P})$ rats: I. Peri-adolescent exposure. Alcohol Clin Exp Res. 2002; 26:1632-1641. [PubMed: 12436051]

Saito M, Smiley J, Toth R, Vadasz C. Microarray analysis of gene expression in rat hippocampus after chronic ethanol treatment. Neurochem Res. 2002; 27:1221-1229. [PubMed: 12462420]

Saito M, Szakall I, Toth R, Kovacs KM, Oros M, Prasad VV, Blumenberg M, Vadasz C. Mouse striatal transcriptome analysis: effects of oral self-administration of alcohol. Alcohol. 2004; 32:223-241. [PubMed: 15282116]

Sanchez-Soria P, Camenisch TD. ErbB signaling in cardiac development and disease. Semin Cell Dev Biol. 2010; 21:929-935. [PubMed: 20933094]

Sartor CE, Lynskey MT, Bucholz KK, Madden PA, Martin NG, Heath AC. Timing of first alcohol use and alcohol dependence: evidence of common genetic influences. Addiction. 2009; 104:15121518. [PubMed: 19686520]

Schumaker VN, Hanson DC, Kilchherr E, Phillips ML, Poon PH. A molecular mechanism for the activation of the first component of complement by immune complexes. Mol Immunol. 1986; 23:557-565. [PubMed: 3018553]

Scott EL, Brann DW. Estrogen regulation of Dkk1 and Wnt/B-catenin signaling in neurodegenerative disease. Brain Res. 2013; 1514:63-74. [PubMed: 23261660]

Smyth GK. Linear models and empirical Bayes methods for assessing differential expression in microarray experiments. Statistical Applications in Genetics and Molecular Biology. 2004; 3(no. 1)

Storey JD, Taylor JE, Siegmund D. Strong control, conservative point estimation, and simultaneous conservative consistency of false discovery rates: A unified approach. J Royal Statistical Soc, Series B. 2004; 66:187-205.

Tabakoff B, Saba L, Printz M, Flodman P, Hodgkinson C, Goldman D, Koob G, Richardson HN, Kechris K, Bell RL, Hubner N, Heinig M, et al. Genetical genomic determinants of alcohol consumption in rats and humans. BMC Biol. 2009; 7:70-78. [PubMed: 19874574]

Treadwell JA, Singh SM. Microarray analysis of mouse brain gene expression following acute ethanol treatment. Neurochem Res. 2004; 29:357-369. [PubMed: 15002731]

Vetreno RP, Crews FT. Adolescent binge drinking increases expression of the danger signal receptor agonist HMGB1 and toll-like receptors in the adult prefrontal cortex. Neurosci. 2012; 226:475488. 
Wadugu B, Kuhn B. The role of neuregulin/ErbB2/ErbB4 signaling in the heart with special focus on effects on cardiomyocyte proliferation. Am J Physiol Heart Circ Physiol. 2012; 302:2139-2147.

Wetherill L, Schuckit MA, Hesselbrock V, Xuei X, Liang T, Dick DM, Kramer J, Nurnberger JI Jr, Tischfield JA, Porjesz B, Edenberg HG, Foroud T. Neuropeptide Y receptor genes are associated with alcohol dependence, alcohol withdrawal phenotypes, and cocaine dependence. Alcohol Clin Exp Res. 2008; 32:2031-2040. [PubMed: 18828811]

$\mathrm{Wu}$ YL, Gong Z. A novel zebrafish kelchlike gene Klhl and its human ortholog KLHL display conserved expression patterns in skeletal and cardiac muscles. Gene. 2004; 338:75-83. [PubMed: 15302408]

Yang QX, Xiang J, Zhou Y, Zhong Q, Li JC. Targeting HMGB1/TLR4 signaling as a novel approach to treatment of cerebral ischemia. Front Biosci. 2010; 2:1081-1091.

Zhu P, Goh YY, Chin HF, Kersten S, Tan NS. Angiopoietin-like 4: a decade of research. Biosci Rep. 2012; 32:211-219. [PubMed: 22458843]

Zhang B, Horvath S. A general framework for weighted gene co-expression network analysis. Stat Appl Genetics Mol Biol. 2005; 4 article 17. 


\section{Highlights}

We examined binge-like alcohol drinking by adolescent alcohol preferring $(\mathrm{P})$ rats Gene expression within two regions of the extended amygdala were determined cAMP signaling genes were up-regulated by adolescent alcohol drinking in both regions Genes for several intracellular signaling pathways were altered by alcohol drinking 


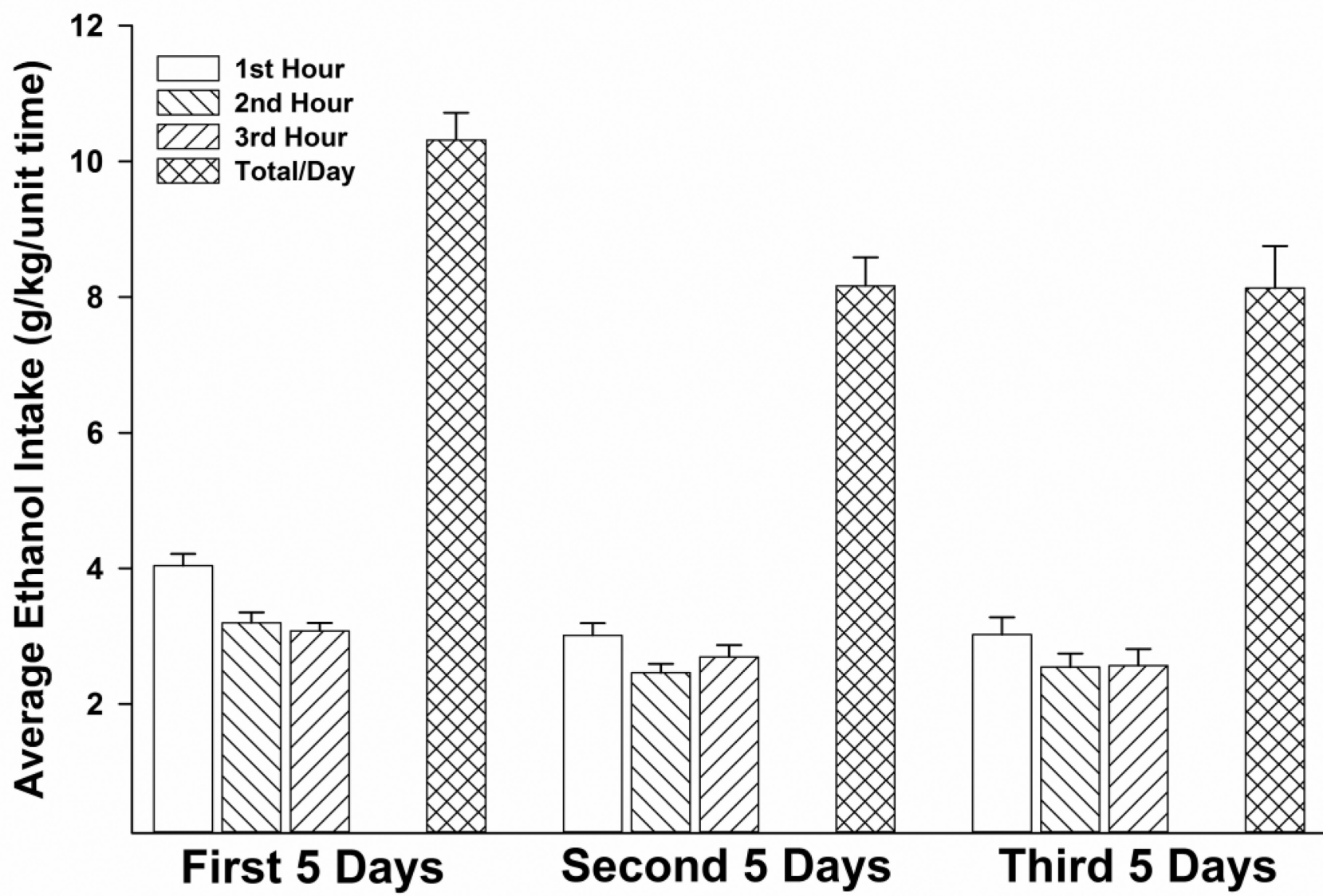

Fig. 1.

Ethanol intakes $(\mathrm{g} / \mathrm{kg})$ by peri-adolescent $\mathrm{P}$ rats averaged over each 5-day period for each of the three one-h periods with concurrent access to 15 and $30 \%$ ethanol (with water freely available) during the dark cycle. Ethanol was given 5 consecutive days each week over the 15 days of access. The average total per day for the 3 one-h sessions is also shown. Data are the means \pm SEM; $\mathrm{n}=10$ ) 


\section{Table 1}

Summary of significant probe sets in the Acb-sh and CeA of adolescent alcohol drinking and control P rats

\begin{tabular}{lrr}
\hline Item & Acb-sh & CeA \\
FDR threshold - Storey & 0.2 & 0.2 \\
Probe sets after A/P filter & 22027 & 22679 \\
total significant probe sets & 306 & 335 \\
total significant ESTs & 143 & 145 \\
total significant probe sets of named genes & 163 & 190 \\
total unique named genes & 154 & 182 \\
\hline
\end{tabular}


Table 2

List of genes that were significantly altered by adolescent alcohol drinking in both the Acb-sh and CeA

\begin{tabular}{|c|c|c|c|}
\hline Symbol & Gene Description & F-C Acb-sh & F-C CeA \\
\hline Angptl4 & angiopoietin-like 4 & -1.19 & -1.21 \\
\hline Atic & 5-aminoimidazole-4-carboxamide ribonucleotide formyltransferase/IMP cyclohydrolase & -1.23 & -1.25 \\
\hline$C 1 s$ & complement component $1, \mathrm{~s}$ subcomponent & -1.33 & -1.42 \\
\hline Ccdc49 & coiled-coil domain containing 49 & 1.37 & 1.29 \\
\hline Cdknla & cyclin-dependent kinase inhibitor $1 \mathrm{~A}$ & -1.26 & -1.55 \\
\hline Chchd5 & coiled-coil-helix-coiled-coil-helix domain containing 5 & 1.25 & 1.26 \\
\hline Chd7 & chromodomain helicase DNA binding protein 7 & -1.16 & -1.30 \\
\hline Cyr61 & cysteine-rich, angiogenic inducer, 61 & 3.83 & 1.56 \\
\hline Duspl & dual specificity phosphatase 1 & 1.88 & 1.57 \\
\hline Fam168a & family with sequence similarity 168 , member A & -1.25 & -1.28 \\
\hline Ier2 & immediate early response 2 & 1.7 & 1.26 \\
\hline Kif15 & kinesin family member 15 & 1.39 & 1.45 \\
\hline Klf3 & Kruppel-like factor 3 (basic) & -1.13 & -1.19 \\
\hline Klhl23 & kelch-like 23 (Drosophila) & 1.15 & 1.11 \\
\hline Limdl & LIM domains containing 1 & -1.14 & -1.20 \\
\hline$M g a$ & MAX gene associated & -1.3 & -1.34 \\
\hline Msn & Moesin & -1.16 & -1.26 \\
\hline Mtfl & metal-regulatory transcription factor 1 & -1.13 & -1.12 \\
\hline Neto 2 & neuropilin (NRP) and tolloid (TLL)-like 2 & 1.2 & 1.23 \\
\hline Npy5r & neuropeptide Y receptor Y5 & 1.23 & 1.36 \\
\hline Nsf & N-ethylmaleimide-sensitive factor & 1.15 & 1.26 \\
\hline$P h b 2$ & Prohibitin 2 & 1.24 & 1.17 \\
\hline Slc25a23 & solute carrier family 25 (mitochondrial carrier; phosphate carrier), member 23 & 1.14 & 1.20 \\
\hline Spl & Sp1 transcription factor & -1.13 & -1.14 \\
\hline Tfrc & transferrin receptor & 1.14 & 1.15 \\
\hline Tnfrsfl1 $1 b$ & tumor necrosis factor receptor superfamily, member $11 \mathrm{~b}$ & 1.63 & 1.35 \\
\hline
\end{tabular}

$\mathrm{F}-\mathrm{C}=$ fold change; negative sign indicates decreased expression in the alcohol drinking group vs. the water control group. 


\section{Table 3}

Significant GO biological processes categories with 10 or more genes or significant KEGG categories with 5 or more genes in the Acb-sh and CeA of adolescent alcohol drinking vs. control P rats

\begin{tabular}{|c|c|c|c|c|}
\hline GO Cat. ID & Term & P-value & Count & Size \\
\hline \multicolumn{5}{|l|}{ Acb-sh } \\
\hline GO:0001568 & blood vessel development & 0.000 & 19 & 260 \\
\hline GO:0048534 & hemopoietic or lymphoid organ development & 0.003 & 11 & 265 \\
\hline GO:0001701 & in utero embryonic development & 0.000 & 14 & 200 \\
\hline GO:0008285 & negative regulation of cell proliferation & 0.007 & 10 & 262 \\
\hline GO:0008284 & positive regulation of cell proliferation & 0.001 & 12 & 297 \\
\hline GO:0022603 & regulation of anatomical structure morphogenesis & 0.001 & 11 & 232 \\
\hline GO:0014070 & response to organic cyclic compound & 0.003 & 10 & 231 \\
\hline \multicolumn{5}{|l|}{ CeA } \\
\hline GO:0007017 & microtubule-based process & 0.012 & 10 & 230 \\
\hline GO:0023061 & signal release & 0.001 & 12 & 214 \\
\hline GO:0035295 & tube development & 0.015 & 11 & 276 \\
\hline GO:0048667 & cell morphogenesis involved in neuron differentiation & 0.018 & 10 & 247 \\
\hline GO:0048812 & neuron projection morphogenesis & 0.010 & 11 & 258 \\
\hline GO:0051130 & positive regulation of cellular component organization & 0.048 & 10 & 290 \\
\hline KEGG Cat. ID & Term & P-value & Count & Size \\
\hline \multicolumn{5}{|l|}{ Acb-sh } \\
\hline 4012 & ErbB signaling pathway & 0.004 & 5 & 66 \\
\hline 4080 & Neuroactive ligand-receptor interaction & 0.01 & 6 & 123 \\
\hline 4310 & Wnt signaling pathway & 0.02 & 5 & 100 \\
\hline 5200 & Pathways in cancer & 0.02 & 8 & 207 \\
\hline 5210 & Colorectal cancer & 0.0001 & 6 & 50 \\
\hline \multicolumn{5}{|l|}{$\mathbf{C e A}$} \\
\hline 4080 & Neuroactive ligand-receptor interaction & 0.03 & 6 & 137 \\
\hline
\end{tabular}




\section{Table 4}

List of significant Ingenuity canonical pathways with 5 or more genes in the AcB-sh and CeA between the adolescent alcohol drinking and control group

\begin{tabular}{|c|c|c|c|}
\hline Ingenuity Canonical Pathways & p-value & Ratio & Molecules \\
\hline \multicolumn{4}{|l|}{ Acb-sh } \\
\hline Ceramide Signaling & 0.00005 & 0.07 & S1PR3, FOS, JUN, S1PR2, S1PR1, TNFRSF11B \\
\hline cAMP-mediated signaling & 0.00007 & 0.04 & $\begin{array}{l}\text { S1PR3, AKAP2/PALM2-AKAP2, CAMK2A, MAPK1, } \\
\text { DUSP1 DUSP6, S1PR1, ADORA2B ADRB2 }\end{array}$ \\
\hline IGF-1 Signaling & 0.00014 & 0.06 & FOS, JUN, CTGF, MAPK1 CYR61, GRB10 \\
\hline Glucocorticoid Receptor Signaling & 0.00030 & 0.03 & $\begin{array}{l}\text { BCL2L1, FOS, NFAT5, JUN MAPK1, DUSP1, } \\
\text { CDKN1A SMAD4, ADRB2 }\end{array}$ \\
\hline $\begin{array}{l}\text { Regulation of IL-2 Expression in Activated and Anergic T } \\
\text { Lymphocytes }\end{array}$ & 0.00047 & 0.06 & FOS, NFAT5, JUN, MAPK1 SMAD4 \\
\hline Human Embryonic Stem Cell Pluripotency & 0.00065 & 0.04 & S1PR3, NTRK2, S1PR2, S1PR1 SMAD4, LEF1 \\
\hline PI3K Signaling in B Lymphocytes & 0.00065 & 0.04 & FOS, NFAT5, JUN, ATF3 CAMK2A, MAPK1 \\
\hline HMGB1 Signaling & 0.00100 & 0.05 & FOS, JUN, SP1, MAPK1 TNFRSF11B \\
\hline Molecular Mechanisms of Cancer & 0.00186 & 0.02 & $\begin{array}{l}\text { BCL2L1, FOS, JUN, CAMK2A MAPK1, CDKN1A, } \\
\text { SMAD4 LEF1, NOTCH1 }\end{array}$ \\
\hline Pancreatic Adenocarcinoma Signaling & 0.00186 & 0.04 & BCL2L1, MAPK1, CDKN1A SMAD4, NOTCH1 \\
\hline $\begin{array}{l}\text { Role of Osteoblasts, Osteoclasts and Chondrocytes in } \\
\text { Rheumatoid Arthritis }\end{array}$ & 0.00204 & 0.03 & $\begin{array}{l}\text { FOS, NFAT5, JUN, MAPK1 SMAD4, LEF1, } \\
\text { TNFRSF11B }\end{array}$ \\
\hline PTEN Signaling & 0.00295 & 0.04 & BCL2L1, NTRK2, MAPK1 CDKN1A, PREX2 \\
\hline RAR Activation & 0.00302 & 0.03 & FOS, JUN, MAPK1, DUSP1 PNRC1, SMAD4 \\
\hline G-Protein Coupled Receptor Signaling & 0.00316 & 0.02 & $\begin{array}{l}\text { S1PR3, S1PR2, CAMK2A MAPK1, DUSP1, ELTD1 } \\
\text { DUSP6, S1PR1, ADORA2B NPY5R, ADRB2 }\end{array}$ \\
\hline Colorectal Cancer Metastasis Signaling & 0.00347 & 0.03 & BCL2L1, FOS, JUN, MAPK1 DCC, SMAD4, LEF1 \\
\hline Protein Kinase A Signaling & 0.00468 & 0.02 & $\begin{array}{l}\text { AKAP2/PALM2-AKAP2 NFAT5, CAMK2A, MAPK1 } \\
\text { DUSP1, DUSP6, DCC, SMAD4 LEF1 }\end{array}$ \\
\hline Aryl Hydrocarbon Receptor Signaling & 0.00575 & 0.03 & FOS, JUN, SP1, MAPK1 CDKN1A \\
\hline B Cell Receptor Signaling & 0.00851 & 0.03 & BCL2L1, NFAT5, JUN CAMK2A, MAPK1 \\
\hline Systemic Lupus Erythematosus Signaling & 0.00955 & 0.02 & FOS, NFAT5, JUN, MAPK1 PRPF4B, PRPF38B \\
\hline Acute Phase Response Signaling & 0.01202 & 0.03 & FOS, JUN, MAPK1, C1S TNFRSF11B \\
\hline $\begin{array}{l}\text { Role of Macrophages, Fibroblasts and Endothelial Cells in } \\
\text { Rheumatoid Arthritis }\end{array}$ & 0.01230 & 0.02 & $\begin{array}{l}\text { FOS, NFAT5, JUN, CAMK2A MAPK1, LEF1, } \\
\text { TNFRSF11B }\end{array}$ \\
\hline Huntington's Disease Signaling & 0.03311 & 0.02 & NSF, BCL2L1, JUN, SP1 MAPK1 \\
\hline \multicolumn{4}{|l|}{$\mathbf{C e A}$} \\
\hline ATM Signaling & 0.0003 & 0.08 & RAD51, CDKN1A, CCNB2, BID CCNB1 \\
\hline HMGB1 Signaling & 0.0023 & 0.05 & SP1, IFNGR2, RHOJ TNFRSF11B, PLAT \\
\hline Hepatic Fibrosis / Hepatic Stellate Cell Activation & 0.0026 & 0.04 & $\begin{array}{l}\text { TIMP1, MYH14, IFNGR2 IGFBP5, PDGFRB, } \\
\text { TNFRSF11B }\end{array}$ \\
\hline cAMP-mediated signaling & 0.0200 & 0.03 & $\begin{array}{l}\text { GRM7, DUSP1, CREM (includes EG:12916), HTR1D, } \\
\text { HRH3 AKAP1 }\end{array}$ \\
\hline
\end{tabular}




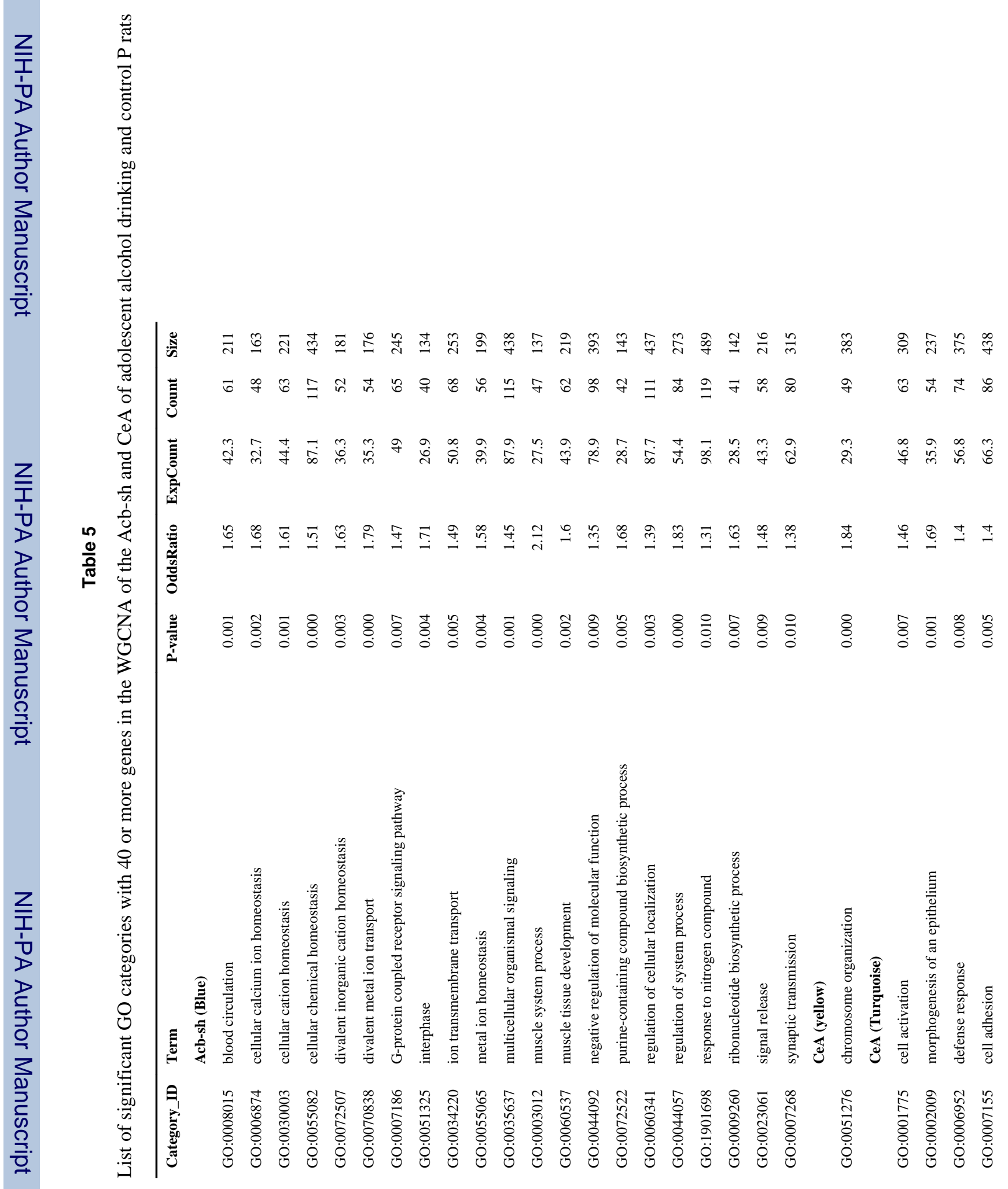




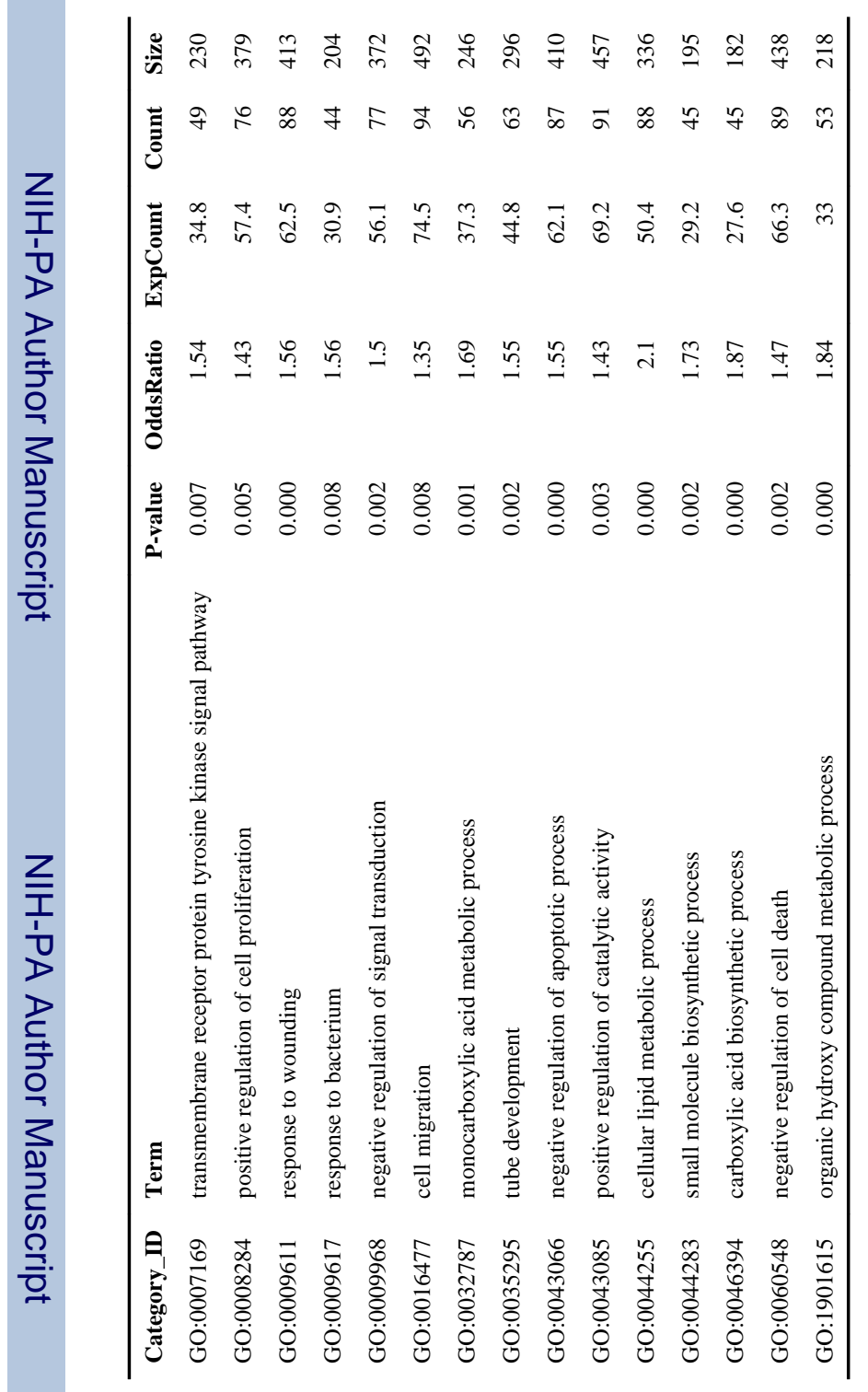




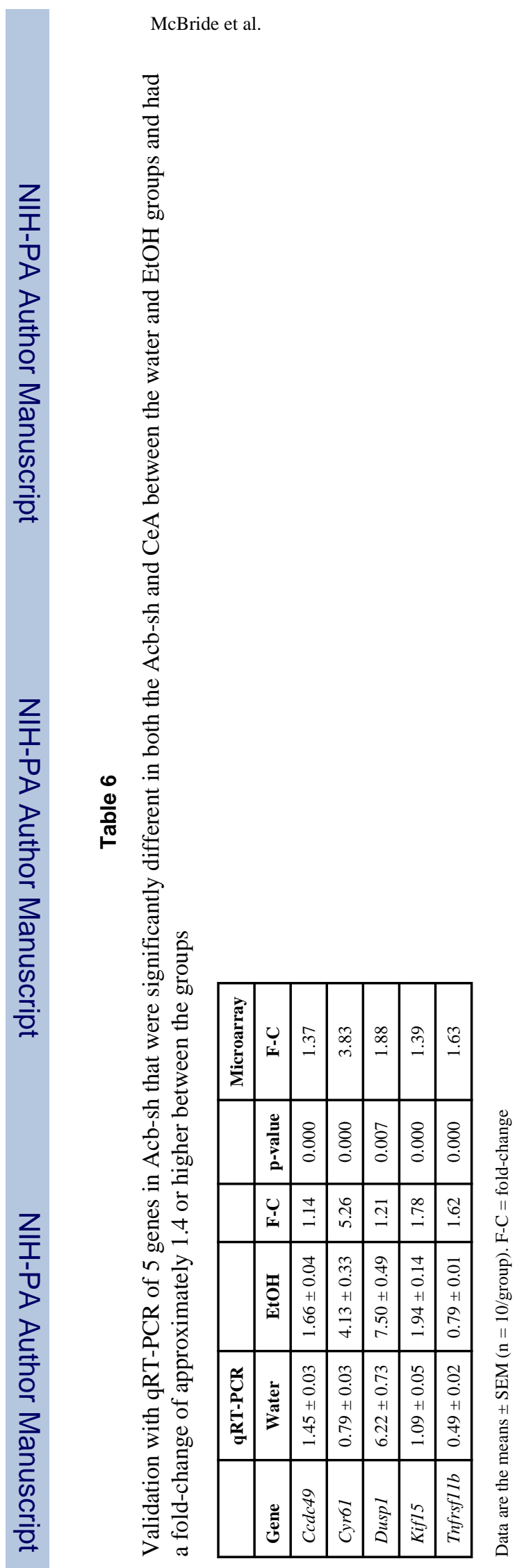

Pharmacol Biochem Behav. Author manuscript; available in PMC 2015 February 01. 